\title{
Impact of Maternal Smoking on the Onset of Breastfeeding versus Formula Feeding: A Cross-Sectional Study
}

\author{
Carolina Lechosa Muñiz ${ }^{1}$, María Paz-Zulueta ${ }^{2, * \mathbb{D}}$, Elsa Cornejo del Río ${ }^{3}$, Sonia Mateo Sota ${ }^{3}$, \\ María Sáez de Adana ${ }^{4}$, María Madrazo Pérez ${ }^{5}$ and María Jesús Cabero Pérez ${ }^{6}$ \\ 1 Hospital Universitario Marqués de Valdecilla, 39008 Santander, Spain; carolina.lechosa@scsalud.es \\ 2 Faculty of Nursing, Universidad de Cantabria, IDIVAL, GI Derecho Sanitario y Bioética, GRIDES, 39008 \\ Santander, Spain \\ 3 Obstetrics Service, Hospital Universitario Marqués de Valdecilla, 39008 Santander, Spain; \\ elsacdelrio@gmail.com (E.C.d.R.); soniamsota@yahoo.es (S.M.S.) \\ 4 Gynecology Service, Hospital Universitario Marqués de Valdecilla, 39008 Santander, Spain; \\ maria.saezdeadana@scsalud.es \\ 5 Faculty of Nursing, University of Cantabria, 39008 Santander, Spain; maria.madrazo@unican.es \\ 6 Pediatrics Service, Hospital Universitario Marqués de Valdecilla, 39008 Santander, Spain; \\ mariajesuscabero@gmail.com \\ * Correspondence: maria.paz@unican.es; Tel.: +34-942-20-16-22
}

Received: 22 November 2019; Accepted: 4 December 2019; Published: 6 December 2019 updates

\begin{abstract}
This study sought to estimate the prevalence of maternal smoking and its association with exclusive breastfeeding vs. formula feeding. A cross-sectional study was performed on postpartum women at a public hospital in Spain, between January and August 2018. The main variables studied were their age, level of study, smoking habits, and chosen mode of infant feeding. In total, 948 postpartum women were included. Of these, $12.45 \%$ were smokers who smoked a mean of 7.23 cigarettes/day. Among the group of smokers, the probability of feeding the newborns with formula milk was multiplied by $2.32([95 \%$ CI 1.50-3.58] $p<0.001)$. When stratifying tobacco use into mild, moderate and severe, we found a statistically significant dose-response pattern. These associations and their statistical significance were maintained when adjusting by age and level of study. In conclusion, in the group of postpartum mothers who smoked, the probability of feeding the newborns with formula milk doubled. Our data highlight the need to improve health education programs in women of childbearing age, especially during pregnancy.
\end{abstract}

Keywords: breastfeeding; newborn; prevalence; tobacco

\section{Introduction}

The World Health Organization (WHO), the American Academy of Pediatrics (AAP), and the Spanish Association of Pediatrics (AEP) recommend exclusive breastfeeding for up to 6 months, and then continued breastfeeding combined with solid foods for 2 years or more, for as long as the mother and baby desire [1,2].

In Spain, according to the National Health Survey of 2017 [3], 74\% of mothers continue to breastfeed at 6 weeks. An important decrease subsequently occurs at 6 months, when only $39 \%$ of mothers breastfeed. These data demonstrate that the current national rates of breastfeeding continue to be below the recommendations of both national and international organizations [4-6].

In Cantabria, the results of the Cantabrian Health Survey of 2006 (ESCAN-06) [7] reveal that maternal breastfeeding progressively decreases from birth until 6 months, at which point infants are 
provided formula milk. Thus, $66.4 \%$ of mothers maintain exclusive breastfeeding until 6 weeks after birth, which then decreases to $45.9 \%$ at 3 months, and $19.4 \%$ at 6 months.

Several studies have found that certain socio-demographic characteristics such as age, parity, level of study, socioeconomic level, and smoking habits can influence the initiation and duration of exclusive breastfeeding [8,9].

The aim of our study was to estimate the prevalence of maternal smoking and its association with the onset of breastfeeding vs. formula feeding, at a hospital of reference within the community.

\section{Materials and Methods}

A cross-sectional study was performed. Based on the study's aims, the required sample size was 805 newborns, therefore, 966 total newborns were recruited, considering the potential attrition or loss of $20 \%$ of the sample. The sample included all the newborns consecutively born until the necessary sample was obtained. The study period was from 1 January 2018 to 31 August 2018.

\subsection{Data Sources}

The data analyzed in this study were obtained based on the clinical records of both the newborn and the mother. The computer applications, Gacela Care and Visor Corporativo, were used to compare or complete the information in cases where the record did not appear in the register. The collected data comprised the age of the mother, their smoking tendency, their level of study, their maternal work status, how many weeks of pregnancy, the newborn weight and the feeding method.

The smoking tendency was classified based on the classification by the WHO, and grouped according to the number of cigarettes smoked, into mild smokers (less than 5 cigarettes per day), moderate smokers (an average of 6 to 15 cigarettes per day), and severe smokers (more than 16 cigarettes per day on average).

Regarding the maternal level of study, this was categorized into primary studies, high school, vocational training, university studies, and postgraduate studies. Work status was categorized into employed, unemployed, inactive or student.

The week of pregnancy variable was categorized into newborn, post-term, full-term, late preterm, very preterm, or extremely preterm [10]. The newborn feeding method was classified as either exclusive breastfeeding (the newborn only receives breast milk), mixed feeding (the newborn receives breastmilk and formula feeding), formula feeding (the newborn has formula milk), or donated milk (the newborn is fed donated human milk).

\subsection{Statistical Analysis}

An initial descriptive analysis was incorporated. For the categorical and discrete variables, proportions were estimated by their corresponding 95\% confidence intervals (95\% CI), using Pearson's chi-squared test for comparisons, or, alternatively, using Fisher's exact test when over $20 \%$ of the fields presented a number of expected cases that were less than or equal to 5 . For the continuous variables, the mean and standard deviation (SD) were estimated. The Kolmogorov-Smirnov test was used to determine the normality of the distribution. Crude and adjusted odds ratios (OR) were estimated with their $95 \% \mathrm{CI}$ using unconditional logistic regression. The alpha error was set at 0.05 and all $p$ values were bilateral. All the statistical analyses were performed using the SPSS v22.0 (IBM SPSS Statistics for Windows. Armonk, NY: IBM Corp.).

\subsection{Ethical Considerations}

This study was approved by the Research Ethics Committee of Cantabria on 21 July, 2017. During the hospital stay after birth, patients were informed of the existence of the study and they were requested to sign the informed consent form to participate in the study. 


\section{Results}

In total, 970 newborns were included. Of these, 50.52\% were male and $49.49 \%$ were female. The mean gestational age at the time of birth was $39.09 \pm 1.96$. Up to $93.81 \%$ were full-term births, $4.02 \%$ were late preterm births and $2.17 \%$ were preterm births. The mean weight at birth was $3244.55 \pm 572.33 \mathrm{~g}$, ranging from 870 to $4840 \mathrm{~g}$. The prevalence of exclusive breastfeeding at hospital discharge was $53.40 \%$ (Table 1).

Table 1. Descriptive analysis of newborns included during the study period (2018).

\begin{tabular}{|c|c|c|c|c|c|}
\hline Variable & $n=970$ & $\%$ & \multicolumn{2}{|c|}{$\mathrm{CI} 95 \% \mathrm{CI}$} & Range \\
\hline male & 490 & 50.52 & 47.32 & 53.71 & \\
\hline female & 480 & 49.49 & 46.29 & 52.68 & \\
\hline Weeks of pregnancy: mean [SD] & 39.09 & 1.96 & & & range $25-42$ \\
\hline Full-term & 910 & 93.81 & 92.25 & 95.38 & \\
\hline Late preterm & 39 & 4.02 & 2.73 & 5.31 & \\
\hline Preterm & 21 & 2.17 & 1.20 & 3.13 & \\
\hline Weight: mean [SD] & 3244.46 & 572.33 & & & range $870-4840$ \\
\hline Normal weight & 806 & 83.09 & 80.68 & 85.50 & \\
\hline Macrosomia & 80 & 8.25 & 6.47 & 10.03 & \\
\hline $\begin{array}{l}\text { Low birth weight } \\
\text { Type of feeding }\end{array}$ & 84 & 8.66 & 6.84 & 10.48 & \\
\hline Exclusive breastfeeding & 518 & 53.40 & 50.21 & 56.59 & \\
\hline Mixed feeding & 272 & 28.04 & 25.16 & 30.92 & \\
\hline Formula feeding & 174 & 17.94 & 15.47 & 20.40 & \\
\hline Donated human milk & 6 & 0.62 & 0.07 & 1.16 & \\
\hline
\end{tabular}

The mean age of postpartum women was $33.7 \pm 5.23$, ranging from 17 to 52 years. Our results revealed statistically significant differences in smoking habits and level of study, when stratified by newborn feeding methods. The remaining sample characteristics are detailed in Tables 2 and 3.

When analyzing smoking tendency, we found that $12.5 \%$ of postpartum women $(n=118)$ were smokers, with a mean consumption of 7.2 cigarettes/day.

In the group of smoking women, the probability of feeding newborns with formula milk was multiplied by 2.32 ([95\% CI, 1.50-3.58] $p<0.001$ ). When stratified by tobacco smoking in mild, moderate and severe, a statistically significant dose-response pattern was found. With a consumption of $\geq 6$ cigarettes/day, the probability of feeding the newborns with formula milk was multiplied by 3.09 ([95\% CI 1.75-5.45]), compared to 1.72 ([95\%CI 0.94-3.18]) in the group of mild consumers. These associations and the statistical significance were maintained when adjusting by age and level of study at 3.09 [95\% CI 1.75-5.45] $p<0.001$ (Table 4). 
Table 2. Descriptive analysis of each of the postpartum women included during the study period (2018).

\begin{tabular}{|c|c|c|c|c|c|}
\hline & $n=948$ & $\%$ * & \multicolumn{2}{|c|}{$95 \% \mathrm{CI}$} & \multirow{2}{*}{$\begin{array}{c}\text { Range } \\
\text { range } 17-52\end{array}$} \\
\hline \multirow{2}{*}{\multicolumn{6}{|c|}{ Twins }} \\
\hline & & & & & \\
\hline no & 926 & 97.68 & 96.67 & 98.69 & \\
\hline yes & 22 & 2.32 & 1.31 & 3.33 & \\
\hline \multicolumn{6}{|l|}{ Smoking } \\
\hline no & 830 & 87.55 & 85.40 & 89.71 & \\
\hline yes & 118 & 12.45 & 10.29 & 14.60 & \\
\hline Number of cigarettes: mean [SD] & 7.23 & 5.25 & & & \\
\hline Maternal educational level & & & & & \\
\hline Did not complete high-school & 214 & 22.57 & 19.86 & 25.29 & \\
\hline High school & 111 & 11.71 & 9.61 & 13.81 & \\
\hline Vocational training & 273 & 28.80 & 25.86 & 31.73 & \\
\hline University studies & 343 & 36.18 & 33.07 & 39.29 & \\
\hline Post-graduate education & 7 & 0.74 & 0.14 & 1.34 & \\
\hline \multicolumn{6}{|l|}{ Work situation } \\
\hline Employed & 660 & 69.62 & 66.64 & 72.60 & \\
\hline Unemployed & 162 & 17.09 & 14.64 & 19.54 & \\
\hline Inactive & 116 & 12.24 & 10.10 & 14.38 & \\
\hline Student & 10 & 1.06 & 0.35 & 1.76 & \\
\hline \multicolumn{6}{|l|}{ Employment } \\
\hline Inactive/unemployed & 275 & 29.01 & 26.07 & 31.95 & \\
\hline Directors and managers & 7 & 0.74 & 0.14 & 1.34 & \\
\hline Technicians/PCSE & 161 & 16.98 & 14.54 & 19.43 & \\
\hline Other technicians/intellectuals & 58 & 6.12 & 4.54 & 7.70 & \\
\hline Technicians/Support professionals & 47 & 4.96 & 3.52 & 6.39 & \\
\hline Office without public & 62 & 6.54 & 4.91 & 8.17 & \\
\hline Office with public & 29 & 3.06 & 1.91 & 4.21 & \\
\hline Catering and retail & 142 & 14.98 & 12.65 & 17.30 & \\
\hline Health and care & 90 & 9.49 & 7.58 & 11.41 & \\
\hline Safety & 1 & 0.11 & 0.00 & 0.59 & \\
\hline Manufacturers and assemblers & 19 & 2.00 & 1.06 & 2.95 & \\
\hline Services sector (not transport) & 53 & 5.59 & 4.08 & 7.11 & \\
\hline Laborers and transport & 4 & 0.42 & 0.12 & 1.08 & \\
\hline
\end{tabular}

* Valid percentage (without considering the missing or unknown data). 
Table 3. Descriptive analysis of postpartum women during the study period (2018) considering the feeding method.

\begin{tabular}{|c|c|c|c|c|c|c|c|c|c|c|c|c|c|c|c|c|c|}
\hline \multirow{2}{*}{$\begin{array}{c}\text { Maternal age: } \\
\text { mean [SD] } \\
\text { Parity }\end{array}$} & \multicolumn{17}{|c|}{ Feeding Method upon Hospital Discharge } \\
\hline & $\begin{array}{c}\mathrm{EB}^{*} \\
n=516 \\
33.68 \\
{[5.02]}\end{array}$ & $\%$ & \multicolumn{2}{|c|}{$95 \% \mathrm{CI}$} & $\begin{array}{c}\text { Mixed } \\
n=262 \\
34.04 \\
{[5.32]}\end{array}$ & $\%$ & \multicolumn{2}{|c|}{$95 \% \mathrm{CI}$} & $\begin{array}{c}\mathrm{FF}^{* *} \\
n=168 \\
33.00 \\
{[5.54]}\end{array}$ & $\%$ & \multicolumn{2}{|c|}{$95 \% \mathrm{CI}$} & $\begin{array}{c}\text { DHM *** } \\
n=4 \\
36.50 \\
{[11.68]}\end{array}$ & $\%$ & \multicolumn{2}{|c|}{$95 \% \mathrm{CI}$} & $\begin{array}{c}p \\
0.156\end{array}$ \\
\hline Primiparous & 257 & 27.05 & 24.18 & 29.30 & 164 & 17.26 & 14.81 & 19.72 & 82 & 8.63 & 6.79 & 10.47 & 2 & 50 & 6.76 & 93.24 & \\
\hline $\begin{array}{l}\text { Multiparous } \\
\text { Smoking }\end{array}$ & 259 & 27.26 & 24.38 & 30.15 & 98 & 10.32 & 8.33 & 10.30 & 86 & 9.05 & 7.18 & 10.93 & 2 & 50 & 0.76 & 93.24 & $<0.001$ \\
\hline no & 465 & 90.12 & 87.44 & 92.79 & 231 & 88.17 & 84.07 & 92.27 & 131 & 77.98 & 71.41 & 84.54 & 4 & 100 & 39.76 & 100 & \\
\hline yes & 51 & 9.88 & 7.21 & 12.56 & 31 & 11.83 & 7.73 & 15.93 & 37 & 22.02 & 15.46 & 28.59 & 0 & 0 & 0 & 60.24 & 0.015 \\
\hline $\begin{array}{c}\mathrm{N}^{\circ} \text { of cigarettes: } \\
\text { mean }[\mathrm{SD}] \\
p \\
\text { Educational } \\
\text { level }\end{array}$ & $\begin{array}{c}6.61 \\
{[5.14]} \\
0.015\end{array}$ & & & & $\begin{array}{c}5.87 \\
{[3.32]} \\
0.018\end{array}$ & & & & $\begin{array}{c}9.28 \\
{[6.20]} \\
0.018\end{array}$ & & & & & & & & \\
\hline Primary studies & 91 & 17.64 & 14.25 & 21.02 & 67 & 25.57 & 20.10 & 31.05 & 56 & 33.33 & 25.91 & 40.76 & 0 & 0 & 0 & 60.24 & \\
\hline High school & 59 & 11.43 & 8.59 & 14.28 & 31 & 11.83 & 7.73 & 15.93 & 21 & 12.5 & 7.201 & 17.8 & 0 & 0 & 0 & 60.24 & \\
\hline $\begin{array}{l}\text { Vocational } \\
\text { training }\end{array}$ & 148 & 28.68 & 24.68 & 32.68 & 69 & 26.34 & 20.81 & 31.86 & 53 & 31.55 & 24.22 & 38.87 & 4 & 100 & 39.76 & 100 & \\
\hline $\begin{array}{c}\text { University } \\
\text { studies }\end{array}$ & 214 & 41.47 & 37.13 & 45.82 & 93 & 35.5 & 29.51 & 41.48 & 37 & 22.02 & 15.46 & 28.59 & 0 & 0 & 0 & 60.24 & \\
\hline $\begin{array}{l}\text { Postgraduate } \\
\text { Work status }\end{array}$ & 4 & 0.78 & 0.21 & 1.973 & 2 & 0.76 & 0.09 & 2.73 & 1 & 0.60 & 0.02 & 3.27 & 0 & 0.00 & 0 & 60.24 & $<0.001$ \\
\hline Employed & 366 & 70.93 & 66.92 & 74.95 & 180 & 68.70 & 62.90 & 74.51 & 113 & 67.26 & 59.87 & 74.66 & 3 & 75.00 & 19.41 & 99.37 & \\
\hline Unemployed & 84 & 16.28 & 13.00 & 19.56 & 46 & 17.56 & 12.76 & 22.36 & 31 & 18.45 & 12.29 & 24.62 & 1 & 25.00 & 0.63 & 80.59 & \\
\hline Inactive & 61 & 11.82 & 8.94 & 14.7 & 32 & 12.21 & 8.06 & 16.37 & 23 & 13.69 & 8.195 & 19.19 & 0 & 0 & 0 & 60.24 & \\
\hline Student & 5 & 0.97 & 0.32 & 2.247 & 4 & 1.53 & 0.42 & 3.86 & 1 & 0.60 & 0.02 & 3.27 & 0 & 0.00 & 0 & 60.24 & 0.975 \\
\hline
\end{tabular}

${ }^{*}$ Exclusive breastfeeding; ${ }^{* *}$ Formula feeding; ${ }^{* * *}$ Donated human milk. 
Table 4. Relationship between maternal smoking and breastfeeding during the study period (2018).

\begin{tabular}{|c|c|c|c|c|c|c|c|c|c|c|c|c|c|c|c|c|c|c|}
\hline \multirow[t]{2}{*}{$n=948$} & \multicolumn{18}{|c|}{ Formula Feeding } \\
\hline & $\mathrm{n}$ & & ORc & $\mathrm{CI}$ & $95 \%$ & $p$ & ORa1 & CI & $95 \%$ & $p$ & ORa2 & CI & $95 \%$ & $p$ & ORa3 & CI & $95 \%$ & $p$ \\
\hline Smoking & no & yes & & & & & & & & & & & & & & & & \\
\hline no & 698 & 132 & 1 & & & & 1 & & & & 1 & & & & 1 & & & \\
\hline yes & 82 & 36 & 2.32 & 1.50 & 3.58 & $<0.001$ & 2.23 & 1.44 & 3.45 & $<0.001$ & 1.95 & 1.25 & 3.04 & 0.003 & 1.94 & 1.24 & 3.03 & 0.004 \\
\hline mild & 46 & 15 & 1.72 & 0.94 & 3.18 & & 1.64 & 0.88 & 3.04 & & 1.51 & 0.81 & 2.80 & & 1.49 & 0.80 & 2.78 & \\
\hline $\mathrm{mod} /$ severe * & 36 & 21 & 3.09 & 1.75 & 5.45 & & 2.98 & 1.68 & 5.28 & & 2.49 & 1.39 & 4.45 & & 2.48 & 1.38 & 4.43 & \\
\hline$p$ trend & & & $<0.001$ & & & & $<0.001$ & & & & 0.001 & & & & 0.001 & & & \\
\hline
\end{tabular}

ORa1: odds ratio adjusted by maternal age—continuous. ORa2: odds ratio adjusted by level of maternal studies. ORa3: odds ratio adjusted by maternal age—continuous, and level of maternal studies. * Moderate and severe consumption: mean consumption $>6$ cigarettes/day. 


\section{Discussion}

The rate of exclusive breastfeeding in full-term infants at hospital discharge was $54.95 \%$, which is a lower average than in other communities [3,11-15]. This continues to be far from the rates required by the Initiative for the Humanization of Assistance to Birth and Lactation (IHAN) initiative, which establishes that at least $75 \%$ of infants should be exclusively breastfed from birth until discharge.

In our study, we found that most mothers opted for breastfeeding, with formula feeding rates of $17.94 \%$. These data are similar to those reported in other parts of Spain. Without addressing gestational age, the prevalence of exclusive maternal breastfeeding at hospital discharge was 53.40\%, 28.04\% received mixed feeding, and $0.6 \%$ were using donated human milk, as our community had a milk bank $[16,17]$.

Bearing in mind the low rates of maternal breastfeeding in our hospital, which are well below those recommended by the WHO, one of the objectives of the Cantabrian Health Service since 2017 has been to improve the practices that promote and protect breastfeeding. Thus, the hospital is immersed in the process of Baby-Friendly Hospital Initiative (BFHI) accreditation, now called the Initiative for the Humanization of Assistance to Birth and Lactation.

The IHAN accreditation is targeted at health professionals working at hospitals, by providing an effective, evidence-based accreditation program, structured and externally evaluated, which enables and facilitates the work of initiating, supporting and increasing the duration of breastfeeding. The IHAN accreditation is a designation which is granted to hospitals that fulfill the following requisites:

1. Fulfill the Ten Steps to a Successful Breastfeeding: based on scientific evidence and approved by national and international agencies as standards of good clinical practice.

2. Implement the Code of Marketing of Breast-milk Substitutes and the related, later resolutions by the World Health Assembly.

3. Embrace at least a $75 \%$ rate of exclusive breastfeeding (from birth until hospital discharge).

4. Furthermore, the mother-child bond must be promoted, regardless of whether or not the mother decides to breastfeed, providing truthful information and support, and instructing them in the preparation and safe administration of bottles of breast milk substitutes.

5. Likewise, a hospital that is accredited is compelled to perform assistance to birth according to the "Strategy of Care for Normal Birth of the National Health System". Therefore, when the clinical situation of the mother and child allows for it, their needs will be respected, the creation of a mother-child bond will be promoted, and the early initiation of breastfeeding will be supported.

The process of obtaining IHAN accreditation in a maternity ward is highly complex, as it entails a significant effort on behalf of the professionals involved and the managers of the institution. To facilitate this, the IHAN suggests a gradual implementation in four phases: Phase 1D (Discovery), Phase 2D (Development), Phase 3D (Dissemination), and Phase 4D (Designation).

On this path towards recovery, studies such as this are highly relevant, in that they provide objective data on the influence of smoking on the initiation of breastfeeding. This paper reveals how a modifiable factor, such as smoking, significantly influences the decision to breastfeed.

Numerous factors have been reported to influence maternal breastfeeding [14,15,18-23]. In our study, we confirmed the significance of the maternal educational level, weeks of pregnancy and smoking tendency.

The prevalence of smoking in the population of pregnant women was $12.5 \%$, with a mean of 7.2 cigarettes/day, which is similar to the number obtained in other communities [24], and very similar to the general population of Spanish women who smoke (18.8\%). These data are sufficiently striking, as with them we can say that $70 \%$ of female smokers continue smoking during their pregnancy. Besides this, we would have to add that the exact prevalence of smoking during pregnancy is hard to identify, because most of the data available are based on declared, self-reported consumption. The studies which use biochemical markers have demonstrated that this prevalence of smoking is greater during pregnancy $[25,26]$. 
The mother's decision to breastfeed her newborn may be influenced by maternal smoking habits, which is in line with previous studies performed in Spain [27,28], Europe [29-32] and internationally. In the latest published meta-analysis, maternal smoking habits are considered a high-impact factor on breastfeeding no smoking vs. smoking ( $R R=1.76$ [IC 95\% 1.59-1.95]) [33]. In the group of women smokers, the probability of feeding the newborns with formula milk was multiplied by 2.32 ([95\%CI 1.50-3.58] $p<0.001$ ). When stratified by smoking consumption into mild, moderate and severe, we found a statistically significant dose-response pattern. Smoking during pregnancy constitutes one of the modifiable risk factors associated with adverse maternal, fetal and neonatal effects [34-41]

In Spain, the Spanish Society of Family and Community Medicine has drafted guidelines for the treatment of active and passive smoking. These guidelines are a reference on how to intervene in the case of patients who smoke and are attending primary care consultations [42], and may be useful for implementing health education programs insisting on smoking cessation for fertile women, as well as pregnant.

\section{Limitations}

In studies based on secondary information (records), one of the main limitations is the low quality of the information. This low quality could be due to inconsistencies in the information provided in different records, or to the insufficient completion of the medical records required for the study. To minimize these biases, prior to the study, we selected the variables which are more homogenously, systematically and objectively gathered in electronic clinical records. Likewise, prior to the definitive inclusion of the variables, the concordance among the data of the different sources used was assessed.

The observational design of this study does not enable the establishment of a causal relationship between variables. However, we can characterize the frequency and/or distribution of the study phenomenon based on the study variables.

Our tobacco consumption data come only from self-reported consumption. Nowadays, we know that it could be made more accurate by using biomarkers, but we were unable to perform a homogeneous and systematic analysis of biomarkers (for example, to conduct an analysis of nicotine/coinine in cord blood). For this reason, such data could not be included in the analyses.

Nonetheless, we have used the same methods as most of the studies published on the rates and prevalence of smoking during pregnancy, which have been performed with data of declared or self-reported consumption [42-46].

\section{Conclusions}

In the group of postpartum mothers who smoked, the probability of feeding the newborns with formula milk doubled. Our data highlight the need to improve health education programs in women of childbearing age, especially during pregnancy. All women of reproductive age who smoke and who hope to have offspring should be offered a health program directed at smoking cessation. This would avoid adverse maternal, fetal and neonatal effects and improve breastfeeding rates.

Author Contributions: Conceptualization, C.L.M., M.P.-Z., E.C.d.R., S.M.S., M.S.d.A., M.M.P. and M.J.C.P.; Data curation, C.L.M., E.C.d.R., S.M.S., M.S.d.A. and M.M.P.; Formal analysis, C.L.M., M.P.-Z. and M.J.C.P.; Funding acquisition, C.L.M., M.P.-Z., E.C.d.R., S.M.S., M.S.d.A., M.M.P. and M.J.C.P.; Investigation, C.L.M., M.P.-Z., E.C.d.R., S.M.S., M.S.d.A., M.M.P. and M.J.C.P.; Methodology, C.L.M., M.P.-Z. and M.J.C.P.; Project administration, C.L.M., M.P.-Z., E.C.d.R., S.M.S., M.S.d.A., M.M.P. and M.J.C.P.; Resources, M.P.-Z., E.C.d.R., S.M.S., M.S.d.A., M.M.P. and M.J.C.P.; Software, C.L.M., M.P.-Z., E.C.d.R., S.M.S., M.S.d.A. and M.M.P.; Supervision, M.P.-Z. and M.J.C.P.; Validation, C.L.M., M.P.-Z. and M.J.C.P.; Visualization, M.P.-Z. and M.J.C.P.; Writing-original draft, C.L.M., M.P.-Z., E.C.d.R., S.M.S., M.S.d.A., M.M.P. and M.J.C.P.; Writing-review \& editing, C.L.M., M.P.-Z. and M.J.C.P. All authors critically revised drafts of the work and approved the final version of the manuscript.

Funding: This research has been subsidized by the Valdecilla Health Research Institute (IDIVAL). Project awarded as the best project to be developed in Cantabria in the 19th call for research projects "Enfermería Valdecilla". The funders had no role in study design, data collection and analysis, decision to publish, or preparation of the manuscript.

Conflicts of Interest: The authors declare no conflict of interest. 


\section{References}

1. World Health Organization; Unicef. Global Strategy for Infant and Young Child Feeding; World Health Organization: Geneva, Switzerland, 2003.

2. Holmes, A.V.; McLeod, A.Y.; Bunik, M. ABM Clinical Protocol \#5: Peripartum breastfeeding management for the healthy mother and infant at term, revision 2013. Breastfeed Med. 2013, 8, 469-473.

3. Ministerio de Sanidad, Servicios Sociales e Igualdad. Instituto Nacional de Estadística. Encuesta Nacional de Salud 2017 [National Health Survey 2017]. Available online: http://www.ine.es/ss/Satellite?L=es_ES\&c= INESeccion_C\&cid=1259926698156\&p=1254735110672\&pagename=ProductosYServicios\%2FPYSLayout (accessed on 14 September 2019).

4. Comité de Lactancia Materna. Asociación Española de Pediatría. Lactancia materna en cifras. 2016. [Breastfeeding in figures, 2016]. Available online: https://www.aeped.es/sites/default/files/documentos/ 201602-lactancia-materna-cifras.pdf (accessed on 14 September 2019).

5. Comité de lactancia materna de la Asociación Española de Pediatría. Manual de Lactancia Materna. De la teoría a la práctica; [Breastfeeding Manual. From Theory to Practice]; Editorial Médica Panamericana: Madrid, Spain, 2008.

6. Asociación Española de Pediatría (AEP). Recomendaciones sobre lactancia materna del comité de lactancia materna de la Asociación Española de Pediatría [Recommendations on breastfeeding by the committee of maternal breastfeeding of the Spanish Association of Pediatrics]. Available online: https://www.aeped.es/comite-lactancia-materna/documentos/recomendaciones-sobre-lactanciamaterna-comite-lactancia-materna (accessed on 14 September 2019).

7. Consejería de Sanidad. Encuesta de Salud de Cantabria [Health Survey of Cantabria]. Gobierno de Cantabria. 2006. Available online: http://saludcantabria.es/index.php/encuesta-de-salud-para-cantabria (accessed on 1 May 2019).

8. Thulier, D.; Mercer, J. Variables associated with breastfeeding duration. JOGNN 2009, 38, 259-268. [CrossRef]

9. Li, R.; Fein, S.B.; Chen, J.; Grummer-Strawn, L.M. Why mothers stop breastfeeding: Mothers' self-reported reasons for stopping during the first year. Pediatrics 2008, 122, S69. [CrossRef]

10. Pallás Alonso, C.R. Grupo PrevInfad/PAPPS Infancia y Adolescencia. Actividades preventivas y de promoción de la salud para niños prematuros con una edad gestacional menor de 32 semanas o un peso inferior a 1500 g. Del alta hospitalaria a los siete años ( $1 .^{\mathrm{a}}$ parte) [Preventive Activities and health promotion for premature children with a gestational age below 32 weeks or a weight below 1500g]. Rev. Pediatr. Aten. Primaria 2012, 14, 153-166.

11. González Herrero, M.; Toledano Bueno, J. La lactancia materna en nuestro medio: Análisis de la situación [Breastfeeding in our environment: Analysis of the situation]. Acta Pediatr. Esp. 2007, 65, 123-125.

12. Ortega García, J.A.; Pastor Torres, E.; Martínez Lorente, I.; Bosh Gimenez, V.; Quesada López, J.J.; Hernandez Ramon, F.; Alcaráz Quiñoneroc, M.; del Castillod, M.M.L.; Torres Canteroe, A.M.; García de León Gonzálezf, R.; et al. Proyecto Malama en la región de Murcia (España): Medio ambiente y lactancia materna [The Malama Project in the region of Murcia (Spain): Environment and breastfeeding]. An. Pediatr. (Barc.) 2008, 68, 447-453. [CrossRef]

13. Cuadrón Andrés, L.; Samper Villagrasa, M.P.; Álvarez Sauras, M.L.; Lasarte Velillas, J.J.; Rodríguez Martínez, G. Prevalencia de la lactancia materna durante el primer año de vida en Aragón. Estudio CALINA [Prevalence of breastfeeding during the first year of life in Aragón. The CALINA Stduy]. An. Pediatr. 2013, 79, 312-318. [CrossRef]

14. Oribe, M.; Lertxundi, A.; Basterrechea, M.; Begiristain, H.; Marina, S.; Villar, M.; Dorronsoro, M.; Amiano, P.; Ibarluzea, J. Prevalencia y factores asociados con la duración de la lactancia materna exclusiva durante los 6 primeros meses en la cohorte INMA de Guipúzcoa [Prevalence and factors associated with duration of exclusive breastfeeding during the first 6 months in the INM cohort of Guipúzcoa]. Gac. Sanit 2015, 29, 4-9.

15. Ramiro, M.D.; Ortiz, H.; Ca, C.A.; Jesús, M.; Olcina, E.; Cortés, O. Prevalencia de la lactancia materna y factores asociados con el inicio y la duración de la lactancia materna exclusiva en la Comunidad de Madrid entre los participantes en el estudio ELOIN [Prevalence of breastfeeding and factors associated with the initiation and duration of exclusive breastfeeding in the Community of Madrid among partipants in the ELOIN study]. Anales de Pediatría 2018, 89, 32-43. 
16. Bancos de Leche en España. [Milk banks in Spain]. Available online: https://www.aeblh.org/banco-de-leche/ bancos-de-leche-en-espana (accessed on 1 May 2019).

17. Banco de Sangre y Tejidos de Cantabria-Banco de Sangre y Tejidos de Cantabria. [Blood and Tissues Bank of Cantabria]. Available online: http://www.bscan.org/index.php/component/content/article/9-destacadosportada/5-banco-de-leche-materna-de-cantabria (accessed on 1 May 2019).

18. Esteves, T.R.B.; Daumas, R.P.; Oliveira, M.I.; Andrade, C.A.; Leite, I.C. Factors associated to breastfeeding in the first hour of life: Systematic review. Rev. Saude Publica 2014, 48, 697-708. [CrossRef]

19. Sacristán, A.M.; Lozano, J.E.; Gil, M.; Vega, A.T. Situación actual y factores que condicionan la lactancia materna en Castilla y León [Current situation and factors which condition breastfeeding in Castilla y León]. Rev. Pediatr. Aten. Primaria 2011, 13, 33-46.

20. Donath, S.M.; Amir, L.H. The relationship between maternal smoking and breastfeeding duration after adjustment for maternal infant feeding intention. Acta Paediatr. Int. J. Paediatr. 2004, 93, 1514-1518. [CrossRef]

21. Chaves, R.G.; Lamounier, J.A.; César, C.C. Fatores associados com a duração do aleitamento materno. J. Pediatr. (Rio. J.) 2007, 83, 241-246. [CrossRef]

22. Wu, X.; Gao, X.; Sha, T.; Zeng, G.; Liu, S.; Li, L.; Chen, C.; Yan, Y. Modifiable Individual Factors Associated with Breastfeeding: A Cohort Study in China. Int. J. Environ. Res. Public Health 2019, 16, 820. [CrossRef]

23. Suzuki, D.; Wariki, W.M.V.; Suto, M.; Yamaji, N.; Takemoto, Y.; Rahman, M. Secondhand Smoke Exposure During Pregnancy and Mothers' Subsequent Breastfeeding Outcomes: A Systematic Review and Meta-Analysis. Sci. Rep. 2019, 9, 1-9. [CrossRef]

24. Mateos-Vílchez, P.M.; Aranda-Regules, J.M.; Díaz-Alonso, G.; Mesa-Cruz, P.; Gil-Barcenilla, B.; Ramos-Monserrat, M.; Moreno-Peral, M.; Castro-Barea, J.; de Dios Luna del Castillo, Y.M. Prevalencia de tabaquismo durante el embarazo y factores asociados en Andalucía. [Prevalence of smoking druing pregnancy and associated facotrs in Andalucía]. 2007-2012. Rev. Esp. de Salud Publica 2014, 88, 369-381. [CrossRef]

25. Swamy, G.K.; Reddick, K.L.; Brouwer, R.J. Prevalencia del tabaquismo al inicio del embarazo: Comparación de autoinforme y análisis de cotinina en orina anónimos [Prevalence of smoking at the start of pregnancy: Comparison of self report and analysis of cotinine in anonymous urine]. J. Matern. Fetal Neonatal Med. 2011, 24, 86. [CrossRef]

26. Hall, E.S.; Wexelblatt, S.L.; Greenberg, J.M. Evaluación autoinformada y de laboratorio de la exposición a la nicotina al final del embarazo y las drogas de abuso [Self-reported assessment and laboratory assessment of exposure to nicotine at the end of pregnancy and drug abuse]. J. Perinatol. 2016, 36, 814. [CrossRef]

27. Alonso, A.; Cano, J.; Girón, A.; Yep, G.; Sánchez, M. Peso al nacimiento y tabaquismo familiar [Weight at birth and family history of smoking]. An. Pediatr. (Barc.) 2005, 63, 116-119. [CrossRef]

28. Sánchez, M.; Cano, C.; García, M.C.; Yep, G.; Pérez, E. Inmigración, lactancia materna y hábito tabáquico [Immigration, breastfeeding and smoking habit]. An. Pediatr. (Barc.) 2008, 68, 462-465. [CrossRef]

29. Bloch, M.; Althabe, F.; Onyamboko, M.; Kaseba-Sata, C.; Castilla, E.E.; Freire, S.; Garces, A.L.; Parida, S.; Goudar, S.S.; Kadir, M.M.; et al. Tobacco use and secondhand smoke exposure during pregnancy: An investigative survey of women in 9 developing nations. Am. J. Public Health 2008, 98, 1833-1840. [CrossRef] [PubMed]

30. Moussa, K.M.; Ostergren, P.-O.; Eek, F.; Kunst, A.E. Are time-trends of smoking among pregnant immigrant women in Sweden determined by cultural or socioeconomic factors? BMC Public Health 2010, 10, 374. [CrossRef] [PubMed]

31. Horta, B.L.; Kramer, M.S.; Platt, R.W. Maternal smoking and the risk of early weaning: A meta-analysis. Am. J. Public Health 2001, 91, 304-307. [PubMed]

32. Joseph, H.M.; Emery, R.L.; Bogen, D.L.; Levine, M.D. The Influence of Smoking on Breast feeding Among Women Who Quit Smoking during Pregnancy. Nicotine Tob. Res. 2017, 19, 652-655. [CrossRef]

33. Cohen, S.S.; Alexander, D.D.; Krebs, N.F.; Young, B.E.; Cabana, M.D.; Erdmann, P.; Hays, N.P.; Bezold, C.P.; Levin-Sparenberg, E.; Turini, M.; et al. Factors Associated with Breastfeeding Initiation and Continuation: A Meta-Analysis. J. Pediatr. 2018, 203, 190-196. [CrossRef]

34. Pineles, B.L.; Hsu, S.; Park, E.; Samet, J.M. Systematic Review and Meta-Analyses of Perinatal Death and Maternal Exposure to Tobacco Smoke During Pregnancy. Am. J. Epidemiol. 2016, 184, 87. [CrossRef] 
35. Bjørnholt, S.M.; Leite, M.; Albieri, V.; Kjaer, S.K.; Jensen, A. Maternal smoking during pregnancy and risk of stillbirth: Results from a nationwide Danish register-based cohort study. Acta Obstet. Gynecol. Scand. 2016, 95, 1305. [CrossRef]

36. Pereira, P.P.; Da Mata, F.A.; Figueiredo, A.C.; de Andrade, K.R.; Pereira, M.G. Maternal Active Smoking During Pregnancy and Low Birth Weight in the Americas: A Systematic Review and Meta-analysis. Nicotine Tob. Res. 2017, 19, 497. [CrossRef]

37. Soneji, S.; Beltrán-Sánchez, H. Association of Maternal Cigarette Smoking and Smoking Cessation with Preterm Birth. JAMA Netw. Open 2019, 2, e192514. [CrossRef]

38. Moore, E.; Blatt, K.; Chen, A.; Van Hook, J.; DeFranco, E.A. Relationship of trimester-specific smoking patterns and risk of preterm birth. Am. J. Obstet. Gynecol. 2016, 215, 109. [CrossRef]

39. Wallace, J.L.; Aland, K.L.; Blatt, K.; Moore, E.; DeFranco, E.A. Modifying the risk of recurrent preterm birth: Influence of trimester-specific changes in smoking behaviors. Am. J. Obstet. Gynecol. 2017, 216, 310. [CrossRef] [PubMed]

40. Perry, M.F.; Mulcahy, H.; DeFranco, E.A. Influence of periconception smoking behavior on birth defect risk. Am. J. Obstet. Gynecol. 2019, 220, 588. [CrossRef] [PubMed]

41. Zhao, L.; Chen, L.; Yang, T. Parental smoking and the risk of congential heart defects in offspring: An updated meta-analysis of observational studies. Eur. J. Prev. Cardiol. 2019. [CrossRef] [PubMed]

42. Camarelles, F.; Mataix, J.; Cabezas, C.; Lozano, J.; Ortega, G. Guía para el tratamiento del tabaquismo activo y pasivo [Guide for the Treatment of Active and Passive Smoking]; Sociedad Española de Medicina Familiar y Comunitaria: Barcelona, Spain, 2011.

43. Colman, G.J.; Joyce, T. Trends in smoking before, during, and after pregnancy in ten states. Am. J. Prev. Med. 2003, 24, 29. [CrossRef]

44. Kmietowicz, Z. Smoking rates among pregnant women fall to all time low of 11\%. BMJ 2015, 350, 3335. [CrossRef]

45. Curtin, S.C.; Matthews, T.J. Smoking prevalence and cessation before and during pregnancy: Data from the birth certificate, 2014. Natl. Vital Stat. Rep. 2016, 65, 1.

46. Cigarette smoking during pregnancy: United States, 2016. Centers for Disease Control and Prevention. National Center for Health Statistics. Available online: https://www.cdc.gov/nchs/products/databriefs/db305. htm (accessed on 28 February 2018). 